\title{
Podział dominikańskich okręgów klasztornych na Kujawach w połowie XIV wieku \\ Studium dokumentu prowincjała Ludolfa z 1517 roku
}

I.

Jesienią 1517 r. odbyła się w Sieradzu kapituła prowincjalna dominikanów polskich. Wybrano wówczas nowego prowincjała Ludolfa ${ }^{1}$ i ogłoszono szereg postanowień, wśród których znalazł się także nakaz: Ne fratres unius conventus terminos alterius conventus mendicandi gratia sine forum licentia speciali ingrediantur, sed unusquisque conventus suis terminis ab antiquo distinctis et sibi appropriatis sit contentus $^{2}$. Poruszony problem musiał być żywo dyskutowany w trakcie obrad, skoro już dzień po ich rozpoczęciu, tj. 30 IX, do prowincjała zgłosili się bracia, zapewne z konwentu toruńskiego, z prośbą o poświadczenie dokumentu, dotyczącego rozgraniczenia okręgów kwestarskich pomiędzy konwentami dominikanów w Toruniu i Brześciu Kujawskim. Prowincjał Ludolf, po stwierdzeniu jego wiarygodności, zarządził sporządzenie pergaminowego widymatu. Aż do XIX w. był on przechowywany w klasztorze toruńskim, a obecnie znajduje się w zbiorach Archiwum Państwowego w Toruniu ${ }^{3}$. Zachowany widymat posiada następującą strukturę. 1) Najstarszą warstwę stanowi opatrzony datą 6 XII 1401 r. dokument w sprawie podziału okręgów kwestarskich na Kujawach, wystawiony przez Stanisława prowincjała polskiego, Teodoryka wikariusza generalnego na prowincję polską oraz sześciu przeorów. 2) Powyższe pismo zostało transumowane przez generała zakonu Tomasza de Firmo; formuła datacyjna tego transumptu podaje jedynie dzień, miesiąc i miejsce wystawienia, po czym następuje anno Domini i pozostawione wolne miejsce. 3) Całość zamyka formuła widymująca prowincjała Ludolfa z 30 IX $1517 \mathrm{r}$.

Dokument znany był historykom od kilkudziesięciu lat ${ }^{4}$, jednak dopiero w ostatnim czasie pojawiły się pierwsze próby analizy jego treści. Maciej Zdanek stwierdził,

${ }^{1}$ R. Ś w i ę t o c how s ki, Ludolf, w: Polski słownik biograficzny (dalej cyt.: PSB), t. XVIII, Wrocław 1973, s. 92-93; M. Z d a n e k, Regensi dominikańskiego studium generalnego w Krakowie do 1596, Przegląd Tomistyczny 16, 2010, s. 114-115.

${ }^{2}$ Acta capitulorum provinciae Poloniae Ordinis Praedicatorum, wyd. R. M. Madura, Roma 1972 (dalej cyt.: ACPP), s. 226-227.

${ }^{3}$ Dokładny opis i edycję dokumentu podaję w aneksie do niniejszego artykułu.

${ }^{4} \mathrm{~K}$. M a j, Początki klasztorów franciszkanów i dominikanów w Toruniu, Rocznik Toruński 13, 1978, s. 227; J. M a n d e c k i, Kultura, życie religijne i codzienne XIV-wiecznego miasta, w: Historia Torunia, t. I, Toruń 1999, s. 231. 
że formuła datacyjna dokumentu prowincjała Stanisława jest ewidentnie błędna i najprawdopodobniej przejęta została $\mathrm{z}$ transumptu generała Tomasz de Firmo. Sam dokument prowincjała powstać miał w połowie XIV w., a zawiera „dane o nieznanej

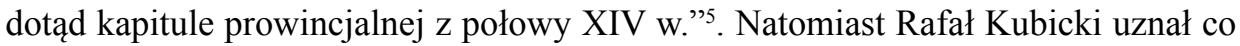
prawda, że najstarszy dokument postał w 1401 r., ale równocześnie zaproponował datowanie transumptu Tomasza de Firmo na 1404 r. ${ }^{6}$ Potem jednak częściowo sprostował swoje poglądy i przychylił się ku chronologii zaproponowanej przez M. Zdanka ${ }^{7}$.

Niewątpliwie problem datacji tych dokumentów nadal wymaga dokładniejszego i szerszego opracowania. Dlatego też w niniejszym studium, oprócz próby rozstrzygnięcia tej kwestii, zajmę się również zagadnieniem ich autentyczności, treścią oraz okolicznościami powstania. W sposób szczególny skoncentruję się na najstarszym dokumencie prowincjała Stanisława. Zważywszy na ubóstwo materiału źródłowego dla XIV w., każda nowa informacja może znacząco wzbogacić, a nawet zmienić, naszą wiedzę na temat polskich dominikanów. Nie inaczej jest również w przypadku omawianego tekstu.

II.

Analizę transumptu wypada rozpocząć od najstarszego z tekstów. Przy pobieżnej lekturze formuła datacyjna transumowanego dokumentu wydaje się pełna i poprawna. Zapisano tam bowiem: Actum anno Domini millesimo quadringentesimo primo in die beati Nicolai episcopi et confessoris, presentibus prioribus superius positis, in quorum omnium testimonium sigilla nostra presentibus sunt appensa. Wątpliwości co do wiarygodności zacytowanej formuły datacyjnej, pojawiają się dopiero przy próbie identyfikacji postaci zakonników, którzy zostali wymienieni w zarówno transumpcie, jak i potwierdzanym dokumencie. Wśród jego wystawców pojawili się: Stanisław prowincjał polskiej prowincji dominikanów; Teodoryk wikariusz generała per provinciam Polonie oraz sześciu przeorów (krakowski, wrocławski, sieradzki, świdnicki, elbląski i brzeski). Współwystępowanie w intytulacji osoby prowincjała i wikariusza generalskiego oraz licznej grupy przeorów nie było przypadkowe. Warto przypomnieć, że wikariusz generalski na prowincję polską był wyznaczany przez generała zakonu oraz kapitułę generalną, gdy pojawiał się wakat na urzędzie prowincjała w danej części zakonu; jego nominacja była odnotowywana w aktach kapituły generalnej w części zatytułowanej absolutiones; do jego zadań należało zwołanie kapituły prowincjalnej, przewodzenie jej obradom i wyborowi prowincjała; jego jurysdykcja wygasała wraz z zatwierdzeniem wyboru prowincjała przez generała (confirmatio

${ }^{5}$ M. Z d a n e k, Fragment akt kapituły prowincjalnej dominikanów polskich z 1338 roku, Roczniki Historyczne 76, 2010, s. 264; zob. także t e n ż e, Stanisław z Krakowa, w: PSB XLII (2003), s. 43.

${ }^{6}$ R. K u b i cki, Działalność dominikanów kontraty pruskiej na pograniczu polsko-krzyżackim. Okręg klasztorny konwentu w Toruniu w XV w., w: Pogranicze polsko-pruskie i krzyżackie (II), Włocławek-Brodnica 2007, s. 381-382; t e n ż e, Środowisko dominikanów kontraty Pruskiej od XIII do połowy XVI wieku, Gdańsk 2007, s. 57.

7 Te n ż e, Miejsce klasztoru toruńskiego w prowincji polskiej dominikanów w średniowieczu, w: Klasztor dominikański w Toruniu w 750. rocznicę fundacji, Toruń 2013, s. 29. 
provincialis) i wprowadzeniem go na urząd (instalatio provincialis) ${ }^{8}$. Omawiany dokument powstał zatem podczas uroczystości kanonicznego rozpoczęcia nowego prowincjalatu. Wymienieni przeorzy byli zapewne definitorami kapituły prowincjalnej, których zadaniem było sygnowanie wraz z legalnie wybranym i potwierdzonym prowincjałem akt prowincjalnych ${ }^{9}$. Biorąc pod uwagę, że tego typu zgromadzenia odbywały się tradycyjnie 29 września, w dniu wspomnienia św. Michała Archanioła, a okres oczekiwania na potwierdzenie wyboru przez generała zakonu wynosił ok. 2 miesięcy, obrzęd objęcia urzędu mógł nastąpić najwcześniej pod koniec listopada lub na początku grudnia. W przytoczonej formule datacyjnej występuje dzień św. Mikołaja Biskupa, tj. 6 grudnia. Wskazane okoliczności potwierdzają prawdziwość tej daty. Do oceny wiarygodności daty rocznej powrócę nieco dalej.

Jako pierwszy w omawianym tu dokumencie wymieniony został prowincjał Stanisław. Powszechnie przyjmuje się, że Stanisław był bezpośrednim następcą Przybysława z Płocka i poprzednikiem Piotra z Chomiąży, a zatem miałby pełnić urząd w latach 1344-1354/1355 ${ }^{10}$. Trzeba jednak jednoznacznie stwierdzić, że wyznaczenie tych właśnie ram czasowych dla jego prowincjalatu oparte było raczej na przypuszczeniach niż mocnych podstawach źródłowych. W 1344 r. na kapitule generalnej w Le Puy urząd złożył Przybysław z Płocka i zgodnie z zakonnym modus procedendi generał wyznaczył swojego wikariusza generalnego na prowincję polską, który miał zająć się organizacją kapituły prowincjalnej - został nim brat Stanisław ${ }^{11}$. Kapituła odbyła się we wrześniu we Wrocławiu i - zdaniem wszystkich badaczy - prowincjałem wybrany został tenże wikariusz. Rzeczywiście, w dokumencie z 29 X 1344 r. pada wzmianka o specjalnej dominikańskiej komisji, powołanej in capitulo nostro Wratislaviensi celebrato fratrum Predicatorum per reverendum patrem Stanislaum vicarium magistri ordinis generalem super provinciam Polonie necnon et definicione ${ }^{12}$. Pismo to powstało miesiąc po wyborze nowego prowincjała, ale jeszcze przed otrzymaniem oficjalnego zatwierdzenia (confirmatio) z kurii generalnej. W oczekiwaniu na decyzję generała najwyższą władzę w prowincji sprawowali wymienieni definitorzy i wikariusz Stanisław. Czy jednak to on właśnie był nowym prowincjałem, tego nie sposób z całą pewnością stwierdzić. Głównym źródłem wiedzy na temat rządów Stanisława są Dictamina litterarum, zawierające formularze stosowane w polskiej kurii

${ }^{8}$ G. R. Galbraith, The Constitution of the Dominican Order 1216 to 1360 , Manchester 1925, s. 105, 125, 149; W. A. H in n e bu s c h, The History of the Dominican Order, t. I, New York 1968, s. 219; T. G a ł u s z k a, Fragment akt kapituły prowincjalnej dominikanów polskich z lat dziewięćdziesiątych XIV wieku. Studium historyczne i edycja tekstu, Roczniki Historyczne 79, 2013, s. 124.

${ }_{9}$ G. R. Galbraith, The Constitution, s. 73-85; W. A. H in ne bu s c h, The History, t. I, s. 186.

${ }_{10}$ R.-J. L o e n ertz, Un ancienne chronique des provinciaux dominicains de Pologne, Archivum Fratrum Praedicatorum 21, 1951, s. 31-33; M. Z d a n e k, Stanisław z Krakowa, s. 43-44.

11 Acta capitulorum generalium Ordinis Praedicatorum, wyd. B. M. Reichert, Romae-Stuttgardiae 1898-1899, Monumenta Ordinis Fratrum Praedicatorum historica, t. I-V (dalej cyt.: MOPH), tu t. II, s. 302.

${ }_{12}$ Preussisches Urkundenbuch, t. III, wyd. M. Hein, Königsberg 1944 - Marburg 1958, nr 674 . 
prowincjalnej w 1. 1338-1411 ${ }^{13}$. Ksiądz Jan Fijałek, w przygotowanej przez siebie edycji tego dzieła, identyfikował aż 13 tekstów, które związane były z działalnością tego prowincjała: $\mathrm{w}$ ośmiu $\mathrm{z}$ nich pojawia się wprost imię Stanisława, natomiast w pozostałych pięciu - imię Jan ${ }^{14}$. Nie jest znana ani data, ani okoliczności zakończenia przez niego prowincjalatu. Według Raymond-Josepha Loenertza prowincjał Stanisław złożył urząd w 1354 r., a w maju następnego roku zmarł. Powyższą interpretację badacz ten oparł na zapisce z powstałego w 1615 r. nekrologu dominikanów krakowskich, w którym pod datą 22 maja odnotowano: F. Stanislaus quondam provincialis Poloniae $1255^{15}$. Dodać jednak trzeba, że pominął inną zapiskę (pod 13 czerwca): Frater Stanislaus provincialis Poloniae $1350^{16}$. Obie daty - o czym być może R.-J. Loenertz nie wiedział - zostały dopisane w XVII w. na podstawie Propago autorstwa Abrahama Bzowskiego ${ }^{17}$. Pozostawiając na uboczu zasadność tych hipotez, należy stwierdzić, że w sierpniu 1356 r. niewątpliwie urzędował już nowy prowincjał Piotr z Chomiąży ${ }^{18}$. Najprawdopodobniej zatem zmiana na urzędzie prowincjała nastąpiła na kapitule prowincjalnej we wrześniu $1355 \mathrm{r}$.

Wracam do rozważanego dokumentu, przekazanego w widymacie z 1517 r. Jak już wspomniano, dokument ten powstał na samym początku prowincjalatu Stanisława, a być może w dniu kanonicznego objęcia przezeń urzędu. Nie sposób jednak pozostać przy przyjmowanej dotychczas dacie rocznej początku jego prowincjalatu (1344). W intytulacji bowiem jako wikariusz generalny na prowincję polską został wymieniony nie Stanisław, ale inny dominikanin: Theodoricus lector Magdeburgensis. Teodoryk de Northen był członkiem prowincji saksońskiej. Stopień lektora zdobył już w 1307 r., a potem zasłynął m.in. tłumaczeniem z języka francuskiego na łacinę traktatu Abrahama bar Hiyya De redemptione filiorum Israel ${ }^{19}$. W Magdeburgu funkcję lektora głównego w prowincjalnej szkole teologii objął po 1350 r., kiedy zastąpił na tym stanowisku Konrada Starszego z Halberstadt ${ }^{20}$. W trakcie sprawowania funkcji wikariusza polskiej prowincji mógł liczyć ponad 70 lat. W aktach sześciu kapituł

${ }^{13}$ Kraków, Archiwum Polskiej Prowincji Dominikanów (dalej cyt.: ADK), sygn. Pp 26; wydanie w: Zbiór formuł Zakonu Dominikańskiego, wyd. J. Fijałek, Kraków 1938 (dalej cyt.: ZF).

${ }_{14} \mathrm{Nr} 162$ (23 V, Stanislaus), 166 (bez daty, Stanislaus), 170 (bez daty, Stanislaus), 171 (ok. 1341-1359, Stanislaus), 209 (przed 1347, Johannes), 213 (bez daty, Stanislaus), 240 (bez daty, Stanislaus), 267 (ok. 1341-1359, Johannes), 275 (przed VIII 1351, Johannes), 276 (ok. 1341-1359, Johannes), 283 (bez daty, Stanislaus), 287 (przed 1364, Johannes), 289 (bez daty, Stanislaus). Uznanie przez wydawcę prowincjałów Jana i Stanisława za jedną i tę samą osobę było logiczną konsekwencją przyjęcia przez wydawcę roku 1344 jako początku prowincjalatu Stanisława.

15 R.-J. L o e n e r t z, Un ancienne chronique, s. 31-32; ADK, sygn. Pp 78: Necrographia, k. $36 \mathrm{v}^{\mathrm{a}}$.

16 Tamże, k. 42ra

17 A. B z ow s k i, Propago divi Hyacinthi thaumaturgi Poloni, Venetiis 1606, s. 58.

18 Regesty śląskie, red. W. Korta, t. I-V, Wrocław 1975-1992, tu t. III, nr 205.

19 T. K a e p p e li, E. P a n e 11 a, Scriptores Ordinis Praedicatorum medii aevi, Roma 1993, t. IV, s. 306-307.

${ }^{20}$ S. P ä t z o ld, Von der Domschule zu den Studia der Bettelorden. Bildung und Wissenschaft im mittelalterlichen Magdeburg, Mitteldeutsches Jahrbuch für Kultur und Geschichte 9, 2002, s. 94. 
generalnych z lat 1345-1350, wśród licznych zwolnień z urzędu prowincjała i nominacji na wikariuszy generalskich brak jakichkolwiek wiadomości o polskiej prowincji i wikariuszu Teodoryku. Nieobecność tego rodzaju danych można wytłumaczyć jedynie w jeden przekonujący sposób - generał zakonu nie widział w tym czasie potrzeby interweniowania $\mathrm{w}$ wewnętrzne sprawy prowincji. W $1351 \mathrm{r}$., z powodu nagłej śmierci generała zakonu, kapituła generalna się nie odbyła i kolejne zgromadzenie miało miejsce dopiero w maju 1352 r. Niestety absolutiones z lat 1352-1358 zaginęły, co było spowodowane - jak przypuszcza R.-J. Loenertz - zaniedbaniem ze strony kopistów ${ }^{21}$. Czyżby zatem w tym właśnie przedziale czasowym nastąpiła zmiana prowincjała polskiego?

Zanim spróbujemy rozstrzygnąć tę kwestię przyjrzyjmy się jeszcze wymienionym $\mathrm{z}$ dokumencie sześciu przeorom-definitorom. Zgodnie z precedencją jako pierwszy wspomniany został Bartłomiej, przeor w Krakowie. Prawdopodobnie jest on tożsamy z Bartłomiejem, dominikaninem krakowskim, który w latach trzydziestych XIV w. otrzymał zgodę ówczesnego prowincjała na wypożyczenie innemu zakonnikowi traktatu teologicznego ${ }^{22}$. Nie jest znana dokładna data rozpoczęcia przez niego kadencji przeorskiej. W 1340 r. funkcję tę sprawował niejaki Bożej, a w maju 1349 r. na kapitule prowincjalnej występuje Stanisław ${ }^{23}$. Wybór Bartłomieja na przeora mógł nastąpić w latach pięćdziesiątych. Jako następni zostali wymienieni dwaj nieznani skądinąd przeorzy wrocławski i sieradzki, obaj o imieniu Piotr. Niestety, nie udało się zrekonstruować pełnej listy przeorów tych konwentów. Nie są znani również kolejni dwaj przeorzy - Jan z Elbląga i Wilhelm z Brzegu. Jednak wzmianka o przeorze Janie jest niezwykle istotna. W 1344 r. kapituła prowincjalna we Wrocławiu, obradując pod przewodnictwem wikariusza Stanisława, powołała komisję złożoną z braci z kontraty pruskiej, wśród których był również przeor elbląski Henryk ${ }^{24}$. Pojawia się więc mocny argument wykluczający datowanie analizowanego dokumentu na $1344 \mathrm{r}$. W grupie przeorów znalazł się wreszcie przeor ze Świdnicy Mikołaj. W źródłach z lat czterdziestych i pięćdziesiątych XIV w. występują trzej przeorzy świdniccy: Konrad (VI 1352), Maciej (V 1355) i Mikołaj Vulbrucke (VIII 1356) ${ }^{25}$. Identyfikacja tego ostatniego z Mikołajem z omawianego dokumentu jest jednak nie do zaakceptowania w świetle innych danych. Stoi bowiem w sprzeczności z przedstawionymi ustaleniami na temat daty zakończenia prowincjalatu Stanisława i objęcia tej funkcji przez jego następcę Piotra z Chomiąży, co nastąpiło przed sierpniem $1356 \mathrm{r}^{26}$

W świetle dotychczasowych ustaleń łatwiej jest wskazać momenty, w których omawiany tekst nie mógł powstać, niż podać w miarę pewną jego datację pozytywną.

${ }^{21}$ R.-J. L o e n e rt z, Un ancienne chronique, s. 6.

22 T. G a ł u s z k a, W przededniu powstania studium generale. Nowe badania nad czternastowiecznym księgozbiorem dominikanów krakowskich, Przegląd Tomistyczny 16, 2010, s. 28-30.

${ }^{23}$ Kodeks dyplomatyczny Małopolski, t. I-IV, wyd. F. Piekosiński, Kraków 1876-1882, tu t. I, nr 212, 689.

${ }^{24}$ Preussisches Urkundenbuch, t. III, nr 674. W aparacie filologicznym edycji tego dokumentu zaznaczono również inny wariant imienia przeora elbląskiego (Mikołaj). Zob. R. K u bi c k i, Środowisko, s. 196.

${ }^{25}$ Regesty śląskie, t. II, nr 695, t. III, nr 64, 305.

${ }^{26}$ Zob. wyżej, przyp. 18. 
Analiza danych na temat wymienionych w dokumencie osób pozwala jednoznacznie wykluczyć lata 1344 i 1355 . Wątpliwości budzą również lata 1345-1350, kiedy to w aktach kapituł generalnych brak jakichkolwiek informacji dotyczących zdjęcia $\mathrm{z}$ urzędu polskiego prowincjała i wyznaczenia wikariusza generalskiego. Pozostają zatem zaledwie trzy lata, w których należałoby poszukiwać genezy pisma prowincjała Stanisława - 1352-1354. Wskazanie lat 1352-1354 jako czasu powstania omawianego dokumentu pociąga za sobą konieczność rewizji i rekonstrukcji dotychczasowej biografii prowincjała Stanisława przed wstąpieniem przez niego na ten urząd. W tym miejscu ograniczymy się tylko do zasygnalizowania kilku obserwacji. Niewątpliwie kapituła prowincjalna zebrana w 1344 r. pod przewodnictwem wikariusza generalskiego Stanisława mogła wybrać na urząd prowincjała jakiegoś innego brata, np. wymienianego w Dictamina Jana ${ }^{27}$, albo też bliżej nieokreślonego brata Stanisława $^{28}$. Swoją kadencję zakończył on przed $1354 \mathrm{r}$. Ów nieznany poprzednik został zdjęty z urzędu przez kapitułę generalną, czego dowodem jest wyznaczenie wikariusza w osobie lektora magdeburskiego Teodoryka. Kim był Stanisław, zanim objął urząd prowincjała? Biorąc pod uwagę biografie jego czternastowiecznych poprzedników, np. Peregryna z Opola $(1305-1312,1322-1327)^{29}$, Mikołaja Afre $(1312-1318)^{30}$, Piotra Polaka (1327-1331) $)^{31}$, Macieja z Krakowa (1331-1337) ${ }^{32}$, a także jego bezpośredniego następcy - Piotra z Chomiąży (1355-1370) $)^{33}$, widzieć w nim należałoby zapewne człowieka wykształconego, legitymującego się tytułem lektora teologii oraz posiadającego doświadczenie organizacyjne, zdobyte w trakcie wcześniejszych kadencji przeorskich (Mikołaj i Maciej byli przeorami konwentu krakowskiego, Peregryn zaś wrocławskiego). Można przypuszczać, że podobnie jak jego poprzednicy pracował w którymś z ważniejszych konwentów prowincji. Powyższe warunki na przełomie lat czterdziestych i pięćdziesiątych spełniało tylko dwóch braci noszących imię Stanisław. Co ciekawe, obaj byli związani z klasztorem w Krakowie. Pierwszy z nich w 1340 r. był przeorem konwentu w Sandomierzu ${ }^{34}$, a następnie w 1349 r. sprawował urząd przeora krakowskiego ${ }^{35}$. Potem nie pojawia się już w znanym materiale źródłowym. Jego identyfikacja z nowym prowincjałem jest o tyle prawdopodobna,

27 Zob. wyżej, przyp. 14.

${ }_{28}$ Zważywszy na popularność imienia Stanisław wśród dominikanów w XIII i XIV w., przypuszczenie to nie jest pozbawione podstaw. Dotychczas w ramach projektu pt. Słownik biograficzny polskich mendykantów w średniowieczu, t. I: Dominikanie, udało się zidentyfikować dla lat 1250-1360 aż 20 braci o imieniu Stanisław.

${ }^{29} \mathrm{~K}$. K a c z m a re k, Szkoły i studia polskich dominikanów w okresie średniowiecza, Poznań 2005, s. 410, nr 73.

${ }^{30}$ R.-J. L o e n e r t z, Un ancienne chronique, s. 28-29.

${ }^{31}$ K. K a c z m a r e k, Szkoły i studia, s. 420, nr 74; T. G a ł u s z k a, W przededniu, s. $37-38$.

${ }^{32}$ K. K a c z m a r e k, Szkoły i studia, s. 414, nr 48; T. G a ł u s z k a, Kolektor Piotr z Auvergne i plebani versus biskup Jan Grotowic i dominikanie. Z badań nad polskimi dominikanami i dziejami diecezji krakowskiej w 1. połowie XIV wieku, Przegląd Historyczny 105, 2014, nr 3, s. 315-337.

${ }^{33}$ R.-J. L o e n e r t z, Un ancienne chronique, s. 28-29; T. Tr z c iń s k i, Średniowieczne rękopisy biblioteki kapitulnej w Gnieźnie, Poznań 1909, s. 233-234.

${ }^{34} \mathrm{ZF}, \mathrm{nr} 315$; Kodeks dyplomatyczny Małopolski, t. I, nr 212.

35 Zob. wyżej, przyp. 23. 
że w omawianym transumpcie jako przeor krakowski wymieniony został już inny brat - Bartłomiej. Byłby on zatem następcą Stanisława, który zwolnił urząd przeora. Drugi Stanisław, którego moglibyśmy utożsamić z prowincjałem, to krakowski lektor, autor Vita sancti Hyacinthi ${ }^{36}$. Pomimo że przedstawiał siebie jako minimus fratrum predicatorum, to lektura jego dzieła nie pozostawia wątpliwości, że ukończył teologiczne studia wyższe, dobrze znał tradycję historyczną i prawną dominikanów oraz troszczył się o wysoki poziom życia zakonnego ${ }^{37}$. Już choćby z tych względów był dobrym kandydatem na urząd prowincjała. Zasadniczy argument, który zdaje się potwierdzać tę hipotezę, odnaleźć można we wspomnianym dziele - ostatni zapisany tam cud św. Jacka nosi datę 22 VII 1352 r. Po tym dniu lektor Stanisław nie powrócił już do swojego dzieła ${ }^{38}$. Przyczyna zaprzestania pracy pisarskiej musiała być rzeczywiście poważna - mógł nim być właśnie wybór na prowincjała w czasie jesiennej kapituły w $1352 \mathrm{r}$.

Na zakończenie rozważań o datowaniu naszego dokumentu warto zatrzymać się jeszcze przy kwestii jego autentyczności. Pomimo widocznych śladów zepsucia tekstu, dokument nie budzi żadnych podejrzeń. Aby jednak definitywnie potwierdzić jego autentyczność, niezbędna jest dokładna analiza innych części formularza. Powrócę do tego w zakończeniu trzeciej części niniejszego studium.

Widymowany w $1517 \mathrm{r}$. dokument zawiera więc niewątpliwie błędną datę roczną (1401). Datę taką mógł zawierać - jak przyjmował M. Zdanek - transumpt. Przypomnę, że w szesnastowiecznym widymacie podano tylko początek zapisu i pozostawiono wolne miejsce na uzupełnienie daty rocznej. Gdyby rzeczywiście w grę wchodziło jedynie pomyłkowe przesunięcie daty, to transumpt został wystawiony 21 XI 1401 r. Propozycja taka nie wytrzymuje jednak konfrontacji z innymi źródłami.

Wystawcą dokumentu był generał zakonu dominikańskiego Tomasz de Firmo, piastujący swój urząd od $15 \mathrm{~V} 1401$ do grudnia 1414 r. ${ }^{39}$ Mógł on zatem kilka miesięcy po swym wyborze przychylić się do prośby polskich dominikanów i potwierdzić dokument w sprawie rozgraniczenia. Sam Tomasz de Firmo był żywo zainteresowany regulacją spraw związanych z okręgami kwestarskimi ${ }^{40}$. Hipoteza ta ma tylko jeden słaby punkt - miejscem wystawienia transumptu był Toruń. Dotychczas nie udało się znaleźć wiarygodnych dowodów potwierdzających pobyt generała Tomasza w polskiej prowincji w $1401 \mathrm{r}^{41}$ Kluczowy dla zakwestionowania tej daty jest jednak

${ }^{36}$ M. Z d a n e k, Stanisław, w: PSB XLII (2003), s. 7-9.

37 Te n ż e, Figury biblijne w literackim wizerunku świętego Jacka w świetle jego najstarszej hagiografii, Przegląd Tomistyczny 14, 2008, s. 29-60.

${ }_{38}$ Kolejne zapisy pojawiły się dopiero w 1488 r. (A. Zajchowska, M. Z danek, „Miracula” świętego Jacka z lat 1488-1500. Edycja krytyczna, Studia Źródłoznawcze 46, 2009, s. 141-152).

${ }^{39}$ A. M orti e r, Histoire des maitres généraux de l'Ordre des Frères Prècheurs, t. V, Paris 1909, s. 1-84.

40 Tamże, s. 27.

${ }^{41} \mathrm{~W}$ wyniku dotychczasowej kwerendy nie udało się odnaleźć żadnych danych na temat ewentualnego pobytu generała Tomasza de Firmo w polskiej prowincji dominikanów. Warto jednak zwrócić uwagę na informację znajdującą się w siedemnastowiecznej kronice konwentu toruńskiego. Przy nocie na temat przeora toruńskiego Piotra Wichmana znajduje się wzmianka o rzekomym pobycie tego generała w konwencie toruńskim (Pelplin, Archiwum 
inny argument: generał wspomina o urzędującym wówczas prowincjale polskim Janie Arnsbergu. W pierwszym dziesięcioleciu XV w. (a zatem w trakcie rządów generała Tomasza de Firmo) J. Fijałek i R.-J. Loenertz dopatrzyli się aż trzech prowincjałów: Andrzeja Rusińca, Jana Strusia i Jana Arnsberga. Andrzej Rusiniec swoją funkcję piastował od 1396 do 1401/1402 r ${ }^{42}$ Dla nas szczególnie ważna jest data zakończenia jego prowincjalatu. Ponieważ ostatni raz pojawia się on $10 \mathrm{X}$ 1401 r., a jego następca Jan występuje w dokumencie z października 1403 r., można uznać, że wyboru nowego prowincjała dokonano na zgromadzeniu w 1402 r. Jego następcą - według J. Fijałka - był Jan Struś, który stał na czele prowincji przez trzy lata ${ }^{43}$. Identyfikacja tego prowincjała została jednak oparta na jednej tylko zapisce z Dictamina, datowanej na $18 \times 1403 \mathrm{r}^{44}$ Występuje tam: frater Jo(hannes) Strus prior provincialis provincie Polonie. Autopsja rękopisu pokazała, że imię zapisane jest skrótem z wyraźną kropką ( $J o$.), a taka sama kropka kończy też zapis nazwiska, w którym w dodatku czytać na pewno należy nie $u$, lecz $n$ - mamy więc nie Strus, lecz Strns. jako formę skrótową. Korekta ta otwiera nowe możliwości identyfikacji nieznanego skądinąd prowincjała. Litery $S t$ są bardzo podobne do uncjalnego minuskulnego $A$, stosowanego na początku rozdziałów. Najprawdopodobniej więc w pierwowzorze figurować mógł Johannes Arns(berg). Prowincjał Jan Arnsberg pochodził z Krakowa i w tutejszym konwencie zapewne złożył śluby zakonne ${ }^{45}$. W 1400 r. był jeszcze przeorem $\mathrm{w}$ Toruniu ${ }^{46}$. W tym charakterze uczestniczył najpewniej we wrześniowej kapitule prowincjalnej w 1402 r., na której wybrano go na prowincjała jako bezpośredniego następcę Andrzeja Rusińca. Czas prowincjalatu Jana jest stosunkowo dobrze oświetlony źródłowo ${ }^{47}$, ale dokładna data i okoliczności zakończenia jego rządów pozostają nieznane. Ponieważ kolejna kapituła wyborcza odbyła się w maju $1411 \mathrm{r}^{48}$, można domniemywać, że Jan zmarł pod koniec 1410 lub na początku

Diecezjalne, sygn. Dominikanie nr 1, k. 3). Autor swoje przypuszczenia oparł na omawianym tutaj widymacie prowincjała Ludolfa z 1517 r. oraz innym, nieznanym nam liście generała Tomasza, skierowanym do konwentu Św. Trójcy w Płocku 1 I 1407 r. Ten ostatni dokument miał dotyczyć podziału okręgów kwestarskich w ziemi dobrzyńskiej. Wiarogodność tego nowożytnego źródła oraz zawartych tam informacji wymaga jednak dodatkowych studiów. Zob. Ł. M y s z k a, Toruńskie archiwalia podominikańskie w Archiwum Diecezjalnym w Pelplinie, Studia Pelplińskie 39, 2008, s. 249-250.

42 J. Fij a łe k, w: ZF, s. 46, oraz R.-J. L o e n e r tz, Un ancienne chronique, s. 38, początek jego prowincjalatu kładli na 1393 r. (zob. także ACPP, s. 16). W ciągu ostatnich lat udało się zweryfikować te ustalenia, zob. A. P a t s c h o v s k y, Spuren böhmischer Ketzerverfolgung in Schlesien am Ende des 14. Jahrhunderts, w: Historia docet. Sborník prací k pocte sedesátych narozenin prof. PhDr. Ivana Hlavácka, Praha 1992, s. 384-385; T. G a ł u s z k a, Fragment akt, s. 122-124.

${ }_{43}$ ZF, s. 45-46; za nim R.-J. L o e n e r t z, Un ancienne chronique, s. 38; ACPP, s. 16.

${ }^{44} \mathrm{ZF}$, nr 99; ADK, Pp 26, k. 26r.

${ }^{45}$ ZF, s. 46; R.-J. L o e n e r t z, Un ancienne chronique, s. 38; ACPP, s. 17.

${ }^{46}$ R. K u bi c k i, Środowisko, s. 162, nr 194.

47 ZF, nr 91, 112, app. 3; Zbiór dokumentów małopolskich, wyd. S. Kuraś, I. SułkowskaKuraś, t. V, Wrocław 1970, nr 1225; Roma, Archivio Generale Dell'Ordine dei Predicatori, sygn. XIV Sect. I A 2 III, k. 2.

48 Joannes Długosz, Liber beneficiorum dioecesis Cracoviensis, t. III, wyd. L. Łętowski, Cracoviae 1864, s. 453. 
$1411 \mathrm{r}^{49}$ Jego rządy przypadają zatem najpewniej na lata 1402-1410/11, a więc nie zgadzają się z podaną $\mathrm{w}$ analizowanym transumpcie $1401 \mathrm{r}$. Podanie niewłaściwej daty mogło być oczywiście spowodowane nieświadomą pomyłką kopisty. Byłby to już jednak kolejny, po nieprawdziwym miejscu wystawienia, błąd. W tej sytuacji trzeba wziąć pod uwagę również i taką ewentualność, że nie chodzi tu o pomyłki kopisty, a lekcje takie znajdowały się już w pierwowzorze dokumentu - w takim razie rodzi się pytanie o jego autentyczność.

Przeciwko jego autentyczności przemawiają co najmniej trzy argumenty. Jak była już mowa, wbrew informacjom zawartym w formule datacyjnej, generał Tomasz de Firmo zapewne nigdy nie był ani w Toruniu, ani w polskiej prowincji. Wzmiankę o Toruniu - o czym więcej za chwilę - można łączyć z głównymi beneficjentami tego dokumentu, czyli dominikanami toruńskimi. Błędna data roczna została wykoncypowana z kilku przesłanek. W 1401 r. Tomasza de Firmo objął urząd generała, co było faktem powszechnie znanym w zakonie - choćby za sprawą licznych nekrologów dominikańskich, w których skrupulatnie notowano daty śmierci poszczególnych generałó $w^{50}$. Prawdopodobnie autor transumptu wiedział, że prowincjał Jan Arnsberg został zatwierdzony przez tego właśnie generała albo że jego prowincjalat przypadał na kadencję Tomasza. W ten sposób doszedł do wniosku, że momentem, w którym mógłby powstać generalski transumpt, był właśnie $1401 \mathrm{r}$. Pisarz jednak nie znał jednego istotnego faktu, że w $1401 \mathrm{r}$. prowincjałem był jeszcze Andrzej Rusiniec, a Jan Arnsberg został wybrany na ten urząd dopiero w 1402 r. ${ }^{51}$ Wreszcie uzasadnione podejrzenia co do autentyczności transumptu budzi osobiste zaangażowanie się generała zakonu w spór pomiędzy dwoma klasztorami, tj. w Toruniu i w Brześciu Kujawskim. W tego typu sprawach kompetentnym i naturalnym organem był prowincjał oraz kapituła prowincjalna. Pominięcie przez generała instytucji na szczeblu prowincjalnym musiałoby się wiązać ze szczególnymi okolicznościami - np. konfliktem $\mathrm{z}$ władzami prowincjalnymi - $\mathrm{i}$ koniecznością ingerencji najwyższych władz zakonu. Dodam jeszcze, że argumentów przeciwko jego autentyczności dostarcza analiza formularza transumptu. Formuła salutacyjna: salutem et Spiritus Sancti consolationem występuje przede wszystkim w korespondencji dwóch szesnastowiecznych generałów - Tomasza de Vio (1508-1518) ${ }^{52}$ i Jana de Loaysa (1518-1524) ${ }^{53}$. Najstarszy znany mi przykład jej użycia w dyplomatyce dominikańskiej znajduje się w liście generała Joachima Torrianiego z 1498 r., skierowanym do dominikanów prowincji teutońskiej ${ }^{54}$.

Na podstawie wszystkich powyższych uwag i obserwacji można sformułować wniosek, że rozważany transumpt jest falsyfikatem. Jego autor posiadał dobrą

${ }_{49}$ ZF, nr 176; R.-J. L o e n e rt z, Un ancienne chronique, s. 38; ACPP, s. 17.

${ }^{50} \mathrm{~Np}$. w nekrologu dominikanów w Brzegu zaznaczono daty śmierci wszystkich generałów aż do początku XVI w. (Wrocław, Biblioteka Uniwersytecka, sygn. IV F 174, k. 1-90).

${ }^{51}$ Nieznajomość dokładnej chronologii prowincjalatów nie jest niczym zaskakującym. Jan Długosz w liście prowincjałów umieszczonej w Liber beneficiorum nie tylko zupełnie pominął Andrzeja Rusińca i Jana Arnsberga, ale nie potrafił nawet ustalić roku objęcia rządów przez współczesnego sobie Jakuba z Bydgoszczy. Zob. J. Kł o c z o w s k i, Polska prowincja dominikańska w średniowieczu i Rzeczypospolitej obojga (wielu narodów), Poznań 2008, s. 70.

${ }_{52}$ MOPH IV, s. 83, 94.

53 Tamże, s. 157, 179.

${ }^{54}$ München, Bayerische Staatsbibliothek, sygn. Clm 3684, k. 2rv. 
znajomość formularza stosowanego w kurii generalnej. Być może inspirował się jakimiś tekstami Tomasza de Firmo, a może nawet nieznaną nam korespondencją generała z konwentem toruńskim. Fałszerstwo było na tyle sprawne, że mogło w XVI w. uchodzić za tekst autentyczny, a wygląd dokumentu nie wzbudzał żadnych podejrzeń u widymującego go w 1517 r. prowincjała Ludolfa.

$\mathrm{Z}$ dużym prawdopodobieństwem można ustalić, że fałszywy transumpt sporządzono przed 1469 r. W latach sześćdziesiątych i siedemdziesiątych XV w. dominikanie toruńscy toczyli spór o prawo zbierania jałmużny na Kujawach aż z dwoma zakonami mendykanckimi - karmelitami i franciszkanami ${ }^{55}$. Karmelici z klasztoru w Bydgoszczy uznali tereny północnych Kujaw za własny okręg kwestarski i ostro sprzeciwiali się konkurencji ze strony dominikanów. Ci ostatni postanowili dochodzić swoich praw i złożyli skargę do prowincjała polsko-czeskiej prowincji zakonu karmelitów Bernarda. Przedłożyli wtedy dwa dokumenty: jakiś nieznany nam dyplom królewski oraz - co ważne - pismo generała swego zakonu, potwierdzające podział okręgów kwestarskich między klasztorami w Toruniu i Brześciu Kujawskim. W odpowiedzi karmelitański prowincjał napisał: significamus, quod venerabilis pater, frater Bernardus sacre theologie lector, prior conventus Thorunensis ordinis predicatorum beati Dominici, nobis certas litteras non solum regales, verum eciam generalis magistri aliorumque dicti ordinis prelatorum exhibuit, metas continentes ac limitationes terminorum predictos prelatos inter dictum conventum et Brestensem factas exposuit ${ }^{56}$. Chodzi oczywiście o rzekomy transumpt Tomasza de Firmo. Odwołanie się do tych dokumentów odniosło pożądane rezultaty i w 1469 r. przełożony karmelitański zakazał swoim bydgoskim współbraciom utrudniania dominikanom działalności kwestarskiej. Prawie równocześnie przeciwko dominikanom wystąpili również franciszkanie z Inowrocławia i Nieszawy. W tym wypadku za dominikanami ujął się czesko-polski prowincjał franciszkanów Mikołaj z Karnowa, który w 1471 r. podjął decyzję o uznaniu praw dominikanów do zbierania jałmużny na tym terenie Kujaw inowrocławskich ${ }^{57}$. Nie wiadomo, jaką tym razem argumentację zastosowali dominikanie, ale można domniemywać, że przywołali te same dokumenty wraz z niedawną decyzją prowincjała Bernarda. Autorem lub głównym inicjatorem powstania fałszywego transumptu generalskiego z pewnością był któryś z dominikanów toruńskich. Jeżeli uznać, że analizowany dokument powstał w przededniu tych sporów, to osobą najbardziej kompetentną, również w zakresie znajomości zakonnych tekstów prawnych, mógłby być przełożony miejscowej wspólnoty, lektor świętej teologii, brat Bernard Galli. Został przeorem przed 1462 i był nim co najmniej do $1473 \mathrm{r}$. Wcześniej został skierowany na trzyletnie studia z prawa kanonicznego do Padwy (1451). Od 1462 r. przebywał w Toruniu, gdzie zajmował urząd lektora i kaznodziei generalnego ${ }^{58}$. Motywy spreparowania falsyfikatu były oczywiste: obrona

${ }^{55}$ R. K u b i c k i, Działalność dominikanów, s. 383-384.

56 Toruń, Archiwum Państwowe, Klasztor oo. Domnikanów, A nr 19; zob. R. K u b i c k i, Działalność dominikanów, s. 384, przyp. 54.

57 Tamże, s. 383; D. K a r c z e w s k i, Franciszkanie w monarchii Piastów i Jagiellonów w średniowieczu, Kraków 2012, s. 154.

${ }^{58}$ K. K a c z m a r e k, Szkoły i studia, s. 439-440, nr 55; K. K u b i c k i, Środowisko, s. $155, \mathrm{nr} 71$. 
interesów dominikanów toruńskich w centralnej i północnej części Kujaw. Ponieważ spór miał być rozstrzygnięty przez przełożonych prowincjalnych karmelitów i franciszkanów, dowody poświadczające ich prawa musiały mieć najwyższą rangę. Nie dziwi zatem fakt, że dominikanie przedłożyli stary dokument prowincjała Stanisława z połowy XIV w. wraz z rzekomym potwierdzeniem ze strony samego generała zakonu Tomasza de Firmo. Ponieważ autor falsyfikatu wiedział, że głównymi adresatami jego „twórczości” będą osoby spoza zakonu, mógł bez obaw wprowadzić nieprawdziwe informacje. Nie wiemy, dlaczego autor falsyfikatu przywołał właśnie generała i prowincjała z pierwszego dziesięciolecia XV w. Może zainspirował się jakąś nieznaną nam korespondencją pomiędzy konwentem toruńskim i generałem Tomaszem. Cała akcja przyniosła w każdym razie zamierzony skutek i toruński konwent mógł przez kolejne lata cieszyć się swobodą w pracy duszpasterskiej na terenie Kujaw inowrocławskich.

III.

Głównym przedmiotem czternastowiecznego dokumentu prowincjała Stanisława był podział okręgów klasztornych na Kujawach. Ponieważ w grę wchodzi wyrok najwyższych władz prowincji, a zatem tekst prawny, dlatego też analizę wypada rozpocząc od krótkiego przeglądu ówczesnego ustawodawstwa dominikańskiego dotyczącego problemu okręgów klasztornych ${ }^{59}$. W średniowiecznych dominikańskich źródłach normatywnych przez pojęcie okręgu klasztornego (limites, termini, praedicatio) rozumiano ściśle określony teren, w obrębie którego bracia mogli prowadzić działalność duszpasterską i kwestarską. Szybki rozwój sieci konwentów dominikańskich i równocześnie duża mobilność dominikanów już w pierwszej połowie XIII w. zmusiły władze zakonu do stworzenia ogólnozakonnych regulacji. Pierwszą ordinatio w sprawie okręgów kwestarskich ogłoszono na kapitule generalnej w Bolonii w 1243 r. Zakazano braciom prowadzenia bez specjalnej zgody prowincjała lub przeora kwesty oraz duszpasterstwa na terenie innej prowincji lub okręgu klasztornego ${ }^{60}$. Przepis ten był powtarzany przez władze zakonu również w następnych latach, a w 1249 r. po raz pierwszy zobowiązano nieposłusznych braci do zwrotu zebranej kwesty $^{61}$. Przypadki lekceważenia owych zarządzeń były jednak na tyle liczne, że kapituła w 1282 r. wezwała wszystkich przełożonych prowincjalnych i klasztornych do bezwzględnego przestrzegania prawa oraz wyznaczyła odpowiednią sankcję za nielegalne przekraczanie granic innych okręgów - były to kary przewidziane

${ }^{59}$ Podstawowe informacje na temat dominikańskich okręgów kwestarskich w średniowieczu zob. W. A. H in ne bu s ch, The History, t. I, s. 265; J. Kł oc zow s ki, Średniowieczne okręgi klasztorne dominikanów mazowieckich, w: Kultura staropolska - kultura europejska, Prace ofiarowane Januszowi Tazbirowi w siedemdziesiątą rocznicę urodzin, Warszawa 1997, s. 149-154; R. K u b i c k i, Działalność dominikanów, s. 275-276; t e n ż e, Środowisko, s. $56-57$.

${ }^{60}$ MOPH I, s. 26: Fratres de una provincia infra terminos alterius provincie non faciant questus, nisi de licencia prioris provincialis vel conventualis, infra cuius terminos questum facere voluerint, nec eciam mittantur ad faciendum moram in predicacione in terminis alterius nisi de consimili licencia.

${ }^{61}$ Tamże, s. 46-47. 
za ciężkie wykroczenia (graves culpae) ${ }^{62}$. Przypomnę, że w ramach tej sankcji zakonnikowi można było nakazać pokutę w postaci kilkudniowego postu o chlebie i wodzie ${ }^{63}$. Od tego momentu kapituły generalne systematycznie poszerzały katalog kar za to przestępstwo. Na mocy zarządzenia kapituły generalnej z 1316 r. dominikanin, który nielegalnie przebywał na terenie innego okręgu, pozbawiany był prawa głosu we wszelkiego typu kapitułach (klasztorna, prowincjalna itp.) na okres jednego roku ${ }^{64}$, a od 1332 r. - przez trzy lata ${ }^{65}$. W XIV w. ujawnił się jeszcze inny problem, mianowicie przeorzy bez uzasadnionej potrzeby i zbyt często wydawali braciom licencję na opuszczanie własnych konwentów. Chcąc temu zaradzić, kapituła w 1312 r. dała prowincjałowi i kapitule prowincjalnej prawo usuwania takich przełożonych z urzędu przeora ${ }^{66}$. Jednak nowy, wręcz przełomowy etap w ustawodawstwie dominikańskim dotyczącym okręgów klasztornych zainicjowała kapituła generalna w Montpellier w 1350 r. ${ }^{67}$ Postanowiono wówczas zrównać samowolną działalność duszpasterską i kwestarską z przestępstwem apostazji zakonnej i włóczęgostwa ${ }^{68}$. Od tej pory każdy z braci, który przekroczył granice innego okręgu, miał być traktowany na równi z uciekinierem i buntownikiem. Kapituła wyznaczyła też odpowiednio surową sankcję, mianowicie którąś z kar przewidzianych w konstytucjach za cięższe wykroczenie (graviores culpae), czyli długotrwały post, chłostę lub izolację $\mathrm{w}$ karcerze zakonnym ${ }^{69}$. Zarządzenie to zostało prawie dosłownie powtórzone na dwóch kolejnych kapitułach generalnych w 1. 1352-1353 ${ }^{70}$. Uchwały z lat

${ }^{62}$ Tamże, s. 219: Cum ex divisione aliorum limitum inter provincias, conventus et fratres consueverit turbacio generari, magister ordinis de diffinitorum ordinacione, consilio et assensu, districte iniungit prioribus provincialibus et conventualibus ac ceteris fratribus, ut limitaciones factas inter provinciam et provinciam studeant exacta diligencia observare et fratres, qui contrarium fecerint, pene gravis culpe subiaceant et quicquid quesierint infra limites alterius provincie, conventibus, in quorum preiudicium hoc fecerint, absque dilacione restituere teneantur.

${ }^{63}$ T. G a ł u s z k a, Kara więzienia w późnośredniowiecznej polityce penitencjarnej dominikanów polskich, Kwartalnik Historyczny 117, 2010, nr 4, s. 67.

${ }^{64}$ MOPH II, s. 90: Fratres vero, qui absque huiusmodi litteris testimonialibus ad conventus quoscumque declinaverint, per priores vel suppriores conventuum, ad quos pervenerint, auctoritate nostra voce ad unum annum priventur et conventui, de quo sunt, hanc privacionem factam significent per suas litteras speciales. Quod si hanc penam privacionis imponere noluerint vel neglexerint, statim cum a suis officiis fuerint absoluti, voce ad unum annum sint ipso facto privati.

${ }_{65}$ Tamże, s. 218.

${ }^{66}$ Tamże, s. 57: Priores vero contra ordinacionem huiusmodi dantes licenciam, in visitacionibus a provinciali et in capitulis provincialibus a prioratus officio absolvantur.

${ }^{67}$ Tamże, s. 333: Quod quicumque frater solus extra conventum discurrerit aut sine licencia sui superioris eciam cum alio fratre discurrerit, noverit se gravioris culpe penam incurrisse, quam sub precepto sancte obediencie per presidentem, in cuius terminis repertus fuerit, facere compellatur, quod si manus suas evaserit, priori provinciali denunciet, ut, quod per eum fieri non potuit, per alium suppleatur.

${ }_{68}^{6}$ T. G a ł u s z k a, Fragmenty, s. 134-135 (tam literatura).

${ }^{69}$ Constitutiones antique Ordinis Fratrum Praedicatorum, c. 23, wyd. A. H. Thomas, w: De oudste constituties van de dominicanen, Leuven 1965, s. 335-338; T. G a ł u s z k a, Kara więzienia, s. 67-68.

${ }^{70}$ MOPH II, s. 341, 351. 
pięćdziesiątych XIV w. są znamiennym świadectwem determinacji najwyższych władz zakonu w regulowaniu spraw związanych $\mathrm{z}$ aktywnością braci oraz przeciwdziałaniem ewentualnym konfliktom pomiędzy klasztorami. Nie dziwi zatem reakcja nowego prowincjała polskiej prowincji, który najprawdopodobniej w 1. 1352-1354 postanowił definitywnie ustalić granice okręgów kwestarskich na terenie Kujaw. Przedsięwzięcie to napotykało trudności ze względu na wydarzenia polityczne, które dotknęły ten region w połowie XIV w.

Rezultatem pierwszej „wielkiej wojny” polsko-krzyżackiej w 1. 1327-1332 była kilkunastoletnia okupacja ziem kujawskiej i dobrzyńskiej. W tym czasie na terenie Kujawach znajdował się jeden klasztor dominikański w Brześciu Kujawskim. Na tym etapie badań nie da się jednoznacznie stwierdzić, czy klasztor ten przed 1332 r., czyli zajęciem miasta przez Krzyżaków, należał do kontraty wielkopolskiej ${ }^{71}$, czy też tworzył osobną kontratę kujawską ${ }^{72}$. Nowa sytuacja polityczna zmusiła konwent brzeski do podjęcia współpracy z kontratą pruską, obejmującą państwo krzyżackie. Trzeba zgodzić się z powszechnie przyjmowaną opinią, że klasztor ten został wówczas włączony w jej struktury ${ }^{73}$. Faktem jest, że w 1335 r. przeor brzeski Bartłomiej wraz z przełożonymi dominikańskich klasztorów w Elblągu, Gdańsku, Chełmnie, Toruniu i Tczewie, a więc całą kontratą pruską, przygotował list do papieża Benedykta XII, w którym usprawiedliwiał politykę krzyżacką ${ }^{74}$. Zdaniem części historyków dominikańska inicjatywa była próbą zyskania przychylności Krzyżaków, na których terytorium znajdowały się okręgi kwestarskie dominikanów ${ }^{75}$. Nie ulega wątpliwości, że w czasie okupacji krzyżackiej w 1. 1332-1343 r. terenami Kujaw zainteresowali się również dominikanie z Torunia. Oczywiście poziom urbanizacji tego regionu był dużo mniejszy niż np. w Wielkopolsce czy na Mazowszu ${ }^{76}$. Jednak z punktu widzenia toruńskich zakonników każde poszerzenie okręgu kwestarskiego było korzystne i pożądane, zarówno z perspektywy duszpasterskiej, jak i finansowej ${ }^{77}$. Jeżeli zaś chodzi o dominikanów w Brześciu Kujawskim, to można tylko domniemywać, że pojawienie się konkurentów, nawet w osobach współbraci, nie spotkało się z ciepłym przyjęciem. Ewentualne protesty nie wchodziły jednak w rachubę choćby z dwóch powodów: jako najmłodsi członkowie kontraty pruskiej potrzebowali wsparcia ze strony braci, którzy mieli mocną pozycję w państwie krzyżackim.

71 J. K ł o c z o w s ki, Średniowieczne okręgi, s. 149; R. K u b i c k i, Środowisko, s. 55; T. G a ł u s z k a, Szkolnictwo konwentualne i partykularne w strukturach polskiej prowincji dominikanów XIV stulecia. Nowe ujęcie w świetle nowych źródeł, Roczniki Historyczne 78, 2012, s. 2006.

${ }_{72}$ J. W i e s i o ł o w s k i, Dominikanie w miastach wielkopolskich w okresie średniowiecza, w: Studia nad historią dominikanów w Polsce 1222-1972, t. I, Warszawa 1975, s. 212.

${ }^{73}$ R. K u b i c k i, Środowisko, s. 55; S. Z o n e n b e r g, Stosunki krzyżacko-dominikańskie w Prusach do 1466 roku, w: Klasztor dominikański w Toruniu (jak w przyp. 7), s. 55.

${ }^{74}$ Lites ac res gestae inter Polonos Ordinemque Cruciferorum, wyd. I. Zakrzewski, t. I, Poznań 1890, nr 23, s. 449-450.

${ }^{75}$ S. Z o n e n b e rg, Stosunki krzyżacko-dominikańskie, s. 54.

76 Z. Guld o n, Lokacje miast kujawskich i dobrzyńskich w XIII-XIV wieku, Ziemia Kujawska 2, 1968, s. 31.

${ }_{77}$ Dominikanie napotykali na problemy w zbiórce jałmużny w samym Toruniu i kontracie pruskiej, zob. R. K u b i c k i, Działalność dominikanów, s. 379. 
Sytuacja w kontracie pruskiej zmieniła się radykalnie wraz z zawarciem w $1343 \mathrm{r}$. traktatu pokojowego w Kaliszu, na mocy którego Kujawy i ziemia dobrzyńska powróciły do Królestwa Polskiego. Dominikanie brzescy prawdopodobnie przypuszczali, że odzyskanie Kujaw pociągnie za sobą przywrócenie dawnych granic ich okręgu kwestarskiego. Okazało się jednak, że bracia z Torunia nie chcieli tak łatwo rezygnować z pozyskanych terenów i prowadzonych tam od przeszło 10 lat dzieł. W czasie okupacji krzyżackiej pojawiła się nowa wspólnota dominikańska w Żninie, blisko zachodniej granicy Kujaw; należała ona do kontraty wielkopolskiej ${ }^{78}$. Tamtejsi braci również prowadzili kwestę na terenie Kujaw. Widzimy zatem, że pokój kaliski stał się początkiem poważnych niepokojów wśród braci z polskiej prowincji dominikanów. Jedna z pierwszych decyzji, jaką podjął nowy prowincjał Stanisław, dotyczyła ich uśmierzenia. Nastąpiło to w obecności wikariusza generalnego na polską prowincję Teodoryka i sześciu przeorów, w tym reprezentantów kontraty pruskiej (Jana przeora w Elblągu) i wielkopolskiej (Piotra przeora w Sieradzu). W dokumencie zostały wymienione tylko dwie miejscowości, które pełniły rolę punktów orientacyjnych przy wyznaczaniu granicy pomiędzy okręgami klasztorów w Toruniu, Brześciu Kujawskim i Żninie - oppidum Gnyskov oraz civitas Vladislawia Iuvenis.

Pierwsza z nich wymaga identyfikacji i pewnego wyjaśnienia. R. Kubicki odczytał tu Guyskov i uznał, że chodzi o Gójsk, wieś leżącą w ziemi dobrzyńskiej ${ }^{79}$. Z kilku jednak powodów trzeba odrzucić tę interpretację. Po pierwsze, Gójsk nie przynależał do Kujaw, a tego właśnie obszaru ewidentnie dotyczy dokument prowincjała Stanisława. Po drugie, była to wieś, a w dokumencie mowa jest wyraźnie o mieście $(\text { oppidum })^{80}$. W spisach parafii dekanatu dobrzyńskiego wieś ta pojawia się dopiero na początku XVI w. ${ }^{81}$ Trudno wreszcie byłoby zrozumieć motywy, jakimi kierowały się władze prowincji, wyznaczając właśnie wieś Gójsk jako punkt orientacyjny w podziale okręgów. Warto także przypomnieć, że rzekomy piętnastowieczny transumpt generała Tomasz de Firmo powstał w kontekście sporów o zbiórkę jałmużny w okolicach Inowrocławia i Nieszawy, czyli na ziemi kujawskiej, położonej po lewej stronie Wisły. Oppidum Gnyskoviense należy uznać za zepsutą formę nazwy miejscowości Gniewkowo, zapisywanej w ówczesnych źródłach jako Gnevkov, Gnewkov, Gnevcov, Gnevov i Gnyfkov ${ }^{82}$.

${ }^{78}$ Klasztor Św. Jana Chrzciciela w Żninie został ufundowany przez arcybiskupa Janisława 29 III 1338 r. (A. H offma n n, Żnińscy dominikanie, Żnin 1992; D. K a r c z e w s k i, Z początków dziejów klasztoru dominikanów w Żninie, Żnińskie Zeszyty Historyczne 12, 1994, s. 4-48).

${ }_{79}$ R. K u bi c k i, Działalność dominikanów, s. 381. s. $31-42$.

${ }^{80}$ Z. G ó ź ḋ́, Warownie obronne na ziemi dobrzyńskiej, Ziemia Dobrzyńska 6, 1999,

${ }^{81}$ Słownik geograficzny Królestwa Polskiego, t. II, Warszawa 1881, s. 651; Z. G u 1 d o n, J. P o w i e r s ki, Podziały administracyjne Kujaw i ziemi dobrzyńskiej w XIII-XIV wieku, Warszawa-Poznań 1974, s. 45, 47, 51, 54, 153, 218; P. G a ł k o w s k i, Drobna szlachta okolic Rogowa w ziemi dobrzyńskiej, Ziemia Dobrzyńska 6, 1999, s. 57.

${ }^{82}$ Kodeks dyplomatyczny Polski, t. II, cz. 2, Warszawa 1852, nr 492; Nazwy miejscowe Polski, red. K. Rymut, t. III, Kraków 1999, s. 191; J. Śl i w iń s k i, Władysław Biały (1327/1333 - 20 luty 1388), ostatni książę kujawski, największy podróżnik spośród Piastów, Kraków 2011, s. 27, 115-116; K. J a s iń s ki, R. K a b a c iń s k i, Cz. S i k or s k i, Gniewkowo w średniowieczu. Książęta, księstwo, miasto, Gniewkowo 1993 (z bibliografią). 
W pierwotnym zapisie było zapewne Gnyfkov-, a w trakcie przygotowywania piętnastowiecznego falsyfikatu lub szesnastowiecznego widymatu kopista błędnie odczytał literę $f$ jako $s$. Zaproponowana identyfikacja jest w pełni zgodna zarówno z sensem całego dokumentu, jak i sytuacją polityczną na Kujawach w połowie XIV w. Gniewkowo było ośrodkiem osobnego księstwa, składającego się z kasztelanii gniewkowskiej i słońskiej ${ }^{83}$. Po 1328 r. była to ostatnia na Kujawach dzielnica książęca. Rządzący nią książęta Kazimierz (zm. przed 1353) i jego syn Władysław Biały starali się utrzymać poprawne stosunki zarówno z królem polskim, jak i Krzyża$\mathrm{kami}^{84}$. Dodam jeszcze, że Władysław współpracował z mieszczaństwem toruńskim ${ }^{85}$. W połowie 1363 r. książę ten oddał swoje władztwo w zastaw królowi Kazimierzowi Wielkiemu i tak to dzielnica gniewkowska znalazła się w ręku królewskim ${ }^{86}$.

Druga z wymienionych w dokumencie miejscowości - Vladislawia Iuvenis - to Inowrocław. Warto zaznaczyć, że zapis jest właściwy dla XIV w. Później, w XV i XVI w., powszechnie używane były nieco inne formy: Iungenleslow, Iunewladislaw, Iunowladislawia, Inowloclawia ${ }^{87}$. Od podziału Kujaw inowrocławskich na trzy księstwa (1314/1315) władzę w Inowrocławiu sprawował Leszek ${ }^{88}$ (do 1323 r.), a po nim jego brat Przemys ${ }^{89}$, książę wyszogrodzko-bydgoski. W 1327 r. przekazał on swe księstwo królowi Władysławowi Łokietkowi w zamian za ziemię sieradzką ${ }^{90}$. Chociaż dzielnice inowrocławska i gniewkowska stanowiły część Kujaw inowrocławskich, to jednak w połowie XIV w. tworzyły one osobne terytoria. Tym, co je łączyło, była wspólna administracja kościelna w ramach diecezji włocławskiej. Oba terytoria należały do dekanatu inowrocławskiego w archidiakonacie kruszwickim. Dekanat ten obejmował co najmniej 18 parafii, w tym najstarsze w Gniewkowie i w Inowrocławiu' ${ }^{91}$.

Przypomniany pokrótce podział administracyjny na Kujawach w drugiej połowie XIV w. jest dobrym punktem wyjścia do prezentacji głównego tematu omawianego dokumentu, czyli wyznaczenia granic dominikańskich okręgów kwestarskich. Prowincjał Stanisław skoncentrował się wyłącznie na obszarze Kujaw inowrocławskich. Stronami sporu były klasztory w Toruniu i w Brześciu Kujawskim, ale na końcu dodana jest decyzja w sprawie roszczeń konwentu w Żninie. Składającymi skargę mogli być zarówno dominikanie toruńscy, jak i brzescy, jednak inicjatorów tego przedsięwzięcia należy najprawdopodobniej poszukiwać w pierwszej ze wspólnot.

83 J. Ś li w i ń s k i, Władysław Biały, s. 30.

${ }^{84}$ K. J a s i ń s k i, Kazimierz - książę gniewkowski i jego rodzina, w: K. Jasiński, R. Kabaciński, Cz. Sikorski, Gniewkowo (jak w przyp. 84), s. 9-17; S. J ó ź w i a k, Powstanie i rozwój struktury administracyjno-terytorialnej zakonu krzyżackiego na Kujawach i w ziemi chełmińskiej w latach 1246-1343, Toruń 1997, s. 71-72.

${ }_{85} \mathrm{R}$. K a b a c i ń s k i, Władysław Biały, w: Inowrocławski słownik biograficzny, Inowrocław 2000, s. 128; J. Śli w iń s ki, Władysław Biały, s. 30.

${ }^{86}$ J. Śli 1 i iń s k i, Władysław Biały, s. 45-46.

${ }^{87}$ Nazwy miejscowe Polski, t. III, s. 531.

88 B. Śli i ińs ki, Leszek książę inowrocławski (1274/1275 - po 27 kwietnia 1339), Kraków 2010.

89 J. B i e n i a k, Przemysł, w: PSB XXVIII (1984), s. 733-735.

90 B. Śliw ińsk i, Leszek, s. 153-158.

${ }^{91}$ Z. Guld o n, J. P ow i er s ki, Podziały administracyjne, s. 21-22. 
Dzięki oficjalnemu wyrokowi mogli oni bowiem skutecznie bronić się przed zarzutami o nielegalną działalność nie tylko na terenie kontraty wielkopolskiej (lub kujawskiej), ale również Królestwa Polskiego. Prowincjał ewidentnie starał się rozwiązać konflikt bez faworyzowania którejkolwiek ze stron. Czytamy w wyroku: fratres conventus Thoronen(sis) omnes villas ad oppidum Gnyskovien(sem), ad Gnyskovien(sem) [!] directe seu indirecte pertinentes, cum Wladislavia Iuveni civitate mendicabunt integraliter et ex toto, et fratres conventus Bresten(sis) reliquas villas ut prius, cum villis et parrochiis, quas fratres conventus Thoronen(sis) immediate pertinentes pronunc ad Regnum mendicare hactenus consueverunt, ipsi integraliter mendicabunt. Dominikanie toruńscy zatem otrzymali prawo zbierania kwesty na obszarze Inowrocławia oraz Gniewkowa wraz z ich przynależnościami. W przypadku Gniewkowa wyraźnie zaznaczono, że chodzi o wszystkie wsie (omnes villas), które podlegają temu miastu w sposób bezpośredni i pośredni (directe seu indirecte pertinentes). To dość oryginalne sformułowanie jest nie tyle prawnym, ile raczej retorycznym podkreśleniem, że chodzi o całość obszaru zarządzanego przez władze w Gniewkowie. Dlatego też uznano za zbędne wyliczanie wszystkich miejscowości, w których mogli prowadzić działalność bracia z Torunia. Do ich okręgu kwestarskiego miał należeć także Inowrocław. Trzeba jednak zauważyć, że w analizowanym dokumencie wzmianka o Inowrocławiu została niejako „dołączona” do okręgu obejmującego księstwo gniewkowskie. Co więcej, podczas lektury wyroku można odnieść wrażenie, że bracia z Torunia mieli pracować jedynie na terenie samego miasta; dokument milczy bowiem o przyległych wsiach. Skoro dokument zachowany jest w sfałszowanym transumpcie, to liczyć się trzeba z tym, że fragment dotyczący Inowrocławia jest późniejszym dopiskiem fałszerza. Granice księstwa gniewkowskiego stykały się bezpośrednio z granicami parafii inowrocławskiej ${ }^{92}$. Dominikanie toruńscy zatem, idąc do Inowrocławia, nie przekraczali granic obcych okręgów kwestarskich. Ponadto obecność dominikanów toruńskich w tym mieście wydaje się w pełni uzasadniona. Dzielnica gniewkowska należała do dekanatu inowrocławskiego. Dominikanie, zbierający jałmużnę i prowadzący posługę duszpasterską przede wszystkim w parafiach, $\mathrm{z}$ pewnością musieli współpracować $\mathrm{z}$ władzami dekanalnymi ${ }^{93}$. Jak zatem widać, autentyczność wzmianki o Inowrocławiu jest wysoce prawdopodobna. Zapewne okręg kwestarski dominikanów toruńskich obejmował nie tylko Inowrocław, ale cały dekanat inowrocławski. W przeciwnym razie należałoby przyjąć, że zachodnia część starostwa inowrocławskiego pozostała w okręgu dominikanów z Brześcia Kujawskiego. W takim razie jednak niezrozumiały byłby zawarty w ciągu dalszym dokumentu zakaz wkraczania na obszar okręgu toruńskiego przez braci z konwentu w Żninie. Najprawdopodobniej więc zachodnia granica okręgu kwestarskiego Torunia była zarazem zachodnią granicą dekanatu inowrocławskiego oraz granicą diecezji włocławskiej i gnieźnieńskiej.

92 Tamże, s. 92.

${ }_{93}$ W 1326 r. plebani dekanatu cieszyńskiego zostali zobowiązani do odczytania mandatu arcybiskupa Janisława, w którym przypominano i potwierdzano prawa mendykantów do słuchania spowiedzi - T. G a ł u s z k a, Dominikanie i spory wokół prawa do słuchania spowiedzi. Recepcja bulli Jana XXII „Vas electionis” w diecezji wrocławskiej w 1. połowie XIV wieku, Studia Źródłoznawcze 52, 2014, s. 3-22. 
Natomiast Kujawy brzeskie stać się miały na mocy wyroku prowincjała Stanisława okręgiem braci z Brześcia Kujawskiego. Prowincjał nie wyznaczył co prawda ani konkretnych granic, ani też jednostek administracyjnych, które podlegały dominikanom brzeskim, jednak brak tego typu informacji łatwo wyjaśnić - klasztor w Brześciu był jedynym domem dominikańskim na terenie Kujaw. Pomimo utraty Kujaw inowrocławskich okręg kwestarski braci z Brześcia był nadal bardzo rozległy i - co szczególnie ważne - „duszpastersko atrakcyjny”. Wspomnę tylko, że w jego granicach znajdowało się kilka ważnych ośrodków miejskich (np. Włocławek, Brześć Kujawski, Radziejów, Kruszwica) oraz funkcjonowało ponad 50 parafii, skupionych w czterech dekanatach: kruszwickim, radziejowskim, brzeskim i raciąskim ${ }^{94}$.

Temat podziału Kujaw na dwa okręgi kwestarskie z pewnością wzbudzał wśród toruńskich i brzeskich dominikanów kontrowersje i spory. Władze prowincji, przewidując ewentualne trudności w trakcie realizacji swych decyzji, przygotowały szereg surowych sankcji. Podzielono je na dwie grupy: kary dla przełożonych i kary dla szeregowych braci. Przełożony, który w jakikolwiek sposób zlekceważyłby wyrok prowincjała, ściągał na siebie z mocy samego prawa zakonnego aż trzy sankcje: zdjęcie z zajmowanego urzędu, utratę prawa głosu na kapitułach zakonu i pozbawienie uczestnictwa w duchownych i doczesnych łaskach zakonu. Zaznaczono również, że zdymisjonowany przełożony nie może obejmować stanowisk przez okres nie krótszy niż trzy lata. Zarządzenie dotyczące czasowego ograniczenia prawa wyborczego, zostało bezpośrednio zaczerpnięte z XX rozdziału Konstytucji zakonnych, traktującego o przestępstwie apostazji zakonnej ${ }^{95}$. Od 1350 r. - o czym wspominałem wyżej wykroczenia związane z nielegalną działalnością duszpasterską były traktowane na równi z samowolnym opuszczeniem zakonu, prowincji lub klasztoru ${ }^{96}$. Co ciekawe, w 1349 r. kapituła generalna w Barcelonie podała oficjalną interpretację przepisu o trzyletnim zakazie sprawowania urzędów przez zakonników oskarżonych o apostazję. Wyjaśniła, że w rozdziale De apostatis sformułowanie: que restitucio non fiat per eosdem ante tres annos ad minus, rozumieć należy: „, non fiat”, hoc est, fieri non possit ullo modo ${ }^{97}$. Dodam, że wyrażenie infra tres annos ad minus zostało powtórzone też w analizowanym dokumencie prowincjała Stanisława. W przypadku kar dla szeregowych zakonników (fratres conventuales) władze nakazały, by traktować ich na równi ze złodziejami. Autor dokumentu, inspirując się zapewne dziełem św. Augustyna Contra Maximum haereticum ${ }^{98}$, opisał tych braci za pomocą literackiego porównania tamquam spoliatores et aliene rei usurpatores. Zgodnie z przepisami zakonu za kradzież przewidziane były kary opisane w rozdziale konstytucji dotyczącym cięższych wykroczeń (graviores culpae) ${ }^{99}$. W piśmie prowincjała określono jednak precyzyjnie rodzaj sankcji - pozbawienie wolności. Zakonnik miał odbyć

${ }_{94}$ Z. G u ld o n, J. P o w i e r s k i, Podziały administracyjne, s. 28-44.

${ }_{95}$ Constitutiones antique, s. 338-339.

96 Zob. wyżej, przyp. 67.

${ }_{97}$ MOPH II, s. 329.

98 Augustinus, Opera omnia, t. VIII, Parisiis 1837, kol. 1049A: Raptor enim rei alienae usurpator est.

99 Zob. wyżej, przyp. 69. 
karę po przeprowadzeniu stosownego postępowania i wydaniu wyroku (sententia diffinitiva). Takimi samymi karami grożono wspomnianym osobno dominikanom ze Żnina, podkreślano też, że dotyczą zarówno przełożonych, jak i zwykłych braci, co oddano słowami quoad caput et quoad membra ${ }^{100}$.

Na koniec powrócę raz jeszcze do kwestii autentyczności czternastowiecznego dokumentu prowincjała Stanisława. Wątpliwości budzi w tej sprawie ustalenie fałszerstwa transumptu, w którym się on zachował. Fałszerz mógł ingerować także w inserowany tekst, a może nawet napisać go od nowa. Wszystkie jednak przeprowadzone dotychczas analizy i obserwacje nie tylko nie dają żadnych podstaw do kwestionowania autentyczności, lecz wręcz przeciwnie - ją potwierdzają. Warto podkreślić, że przedstawiony w niniejszym studium wyrok prowincjała Stanisława jest najstarszym znanym świadectwem wyznaczania okręgów klasztornych w polskiej prowincji dominikanów ${ }^{101}$.

\section{IV.}

Najważniejsze ustalenia poczynione w trakcie powyższych rozważań ująć można w następujących punktach:

1) w trakcie kapituły prowincjalnej w Sieradzu nowo wybrany prowincjał Ludolf widymował 30 IX 1517 r. przedstawiony mu transumpt dokumentu jego poprzednika Stanisława w sprawie rozgraniczenia okręgów klasztornych na Kujawach.

2) Transumpt ów, wbrew dotychczasowym sugestiom, nie pochodzi z 1401 r., ale okazał się falsyfikatem. Jego wystawcą miał być bowiem generał zakonu Tomasz de Firmo (1401-1414), a w tekście wspomniany został również polski prowincjał Jan Arnsberg (1402-1410). Falsyfikat ten powstał najprawdopodobniej przed 1469 r. w związku ze sporami dominikanów toruńskich z franciszkanami i karmelitami o prawo do zbiórki jałmużny na terenie Kujaw inowrocławskich.

3) Fałszywy transumpt zawiera jednak autentyczny dokument czternastowieczny, wystawiony przez prowincjała Stanisława wraz z wikariuszem generalnym na polską prowincję, lektorem magdeburskim Teodorykiem i sześcioma przeorami. Dokument ma datę dzienną (6 XII), a powstał prawdopodobnie w 1. 1352-1354 przy okazji oficjalnego zatwierdzenia wyboru nowego prowincjała i ogłoszenia akt jesiennej kapituł prowincjalnej.

4) Dokument prowincjała Stanisława jest wyrokiem w sprawie rozgraniczenia okręgów kwestarskich na Kujawach. Stronami były konwenty dominikańskie w Toruniu i Brześciu Kujawskim. Decyzją władz prowincji konwent toruński otrzymał prawo kwestowania na terenie dekanatu inowrocławskiego, obejmującego tereny księstwa gniewkowskiego i starostwa inowrocławskiego; dominikanie brzescy natomiast mieli prowadzić działalność duszpasterską na obszarze Kujaw brzeskich.

${ }^{100} \mathrm{~W}$ sformułowaniu tym nie trzeba doszukiwać się wpływu piętnastowiecznego motta reformatio in capite et in membris. Wyrażenie to bowiem pojawia się często $\mathrm{w}$ dominikańskich tekstach normatywnych z XIII i XIV w., np. w aktach kapituł generalnych w 1. 1278, 1291, 1303, 1307, 1312 (MOPH I, s. 199, 263, 322, II, s. 27, 61).

${ }^{101}$ Następne przykłady pochodzą dopiero z początku XV w. (J. Kłoc zow ski, Średniowieczne okręgi, s. 150). 
5) W ,aneksie” wyroku zajęto się również ewentualnymi roszczeniami dominikanów wielkopolskich z klasztoru w Żninie, którym zakazano wkraczania w granice okręgu toruńskiego.

6) W trakcie analiz udało się zweryfikować i poprawić niektóre informacje dotyczące listy dominikańskich prowincjałów w średniowieczu:

Wspomniany w czternastowiecznym wyroku prowincjał Stanisław objął ów urząd najprawdopodobniej w 1. 1352-1354 i sprawował go do 1355 r. Na obecnym etapie badań nie sposób wskazać z całą pewnością, kto piastował tę funkcję w 1. 1344-1352. Być może był to wspomniany w Dictamina litterarum Jan lub jakiś inny Stanisław.

Ponowna analiza źródeł do biografii piętnastowiecznego prowincjała Jana Arnsberga pozwoliła skorygować chronologię jego urzędowania. W powszechnie przyjmowanych listach prowincjałów Jan Arnsberg występuje jako następca nieznanego skądinąd Jana Strusia, który miał sprawować urząd w 1. 1402-1404. Okazuje się jednak, że pojawienie się tego ostatniego w oficjalnym spisie prowincjałów było wynikiem błędnego odczytu z Dictamina litterarum. Prowincjał Jan Struś nigdy nie istniał, a kryje się pod nim Jan Arnsberg. Był on zatem bezpośrednim następcą Andrzeja Rusińca (1396-1401/1402) i stanął na czele prowincji zapewne już w 1402 r.

\section{ANEKS}

Edycję rozważanego dokumentu przygotowano zgodnie z wytycznymi sformułowanymi przez Adama Wolffa ${ }^{102}$. Zrezygnowano z przypisów rzeczowych, ponieważ wszystkie osoby i miejscowości omówione zostały w tekście artykułu.

[Sieradz], 30 września 1517 Ludolf prowincjał polskiej prowincji dominikanów widymuje dokument Tomasza de Firmo generała tegoż zakonu, który transumuje i potwierdza dokument wystawiony przez Stanisława prowincjała polskiego, Teodoryka wikariusza generalnego na prowincję polska oraz sześciu przeorów w sprawie podziału okręów kwestarskich na Kujawach.

Or.: Toruń, Archiwum Państwowe, Klasztor OO. Dominikanów, A nr 23; pergamin 29 x 34,5 + 40 mm; stan zachowania dobry, brąowa plama w środkowej czéści dokumentu; fragment pergaminowego paska do przewieszenia pieczęci, pieczęci brak; na odwrociu nowożytna informacja o treści dokumentu, pieczątka i sygnatura archiwalna.

In Dei Filio sibi charissimis fratribus, priori ceterisque omnibus conventus Bresten(sis) provincie Polonie ordinis predicatorum frater Thomas de Firmo, sacre theologie professor ac totius eiusdem ordinis humilis magister et servus, salutem et Spiritus Sancti consolationem. Cum quidam ex vobis prout accepi in quibusdam terminis ad conventum Thoronen(sem) spectantibus mendicare non vereantur, non obstante, quod $\mathrm{ab}$ olim per protunc provincialem et vicarium generalem de consilio et consensu multorum patrum dicte provincie propter parem conventuum predictorum ad invicem

${ }^{102}$ A. Wolff, Projekt instrukcji wydawniczej dla pisanych źródeł historycznych do połowy XVI wieku, Studia Źródłoznawcze 1, 1957, s. 155-184. 
conservandam distinctio terminorum facta fuerit et ${ }^{a}$ in scripto redacta, prout patet ex litteris eorundem provincialis et vicarii sigillis munitis, coram me productis, ostensis atque lectis, quorum tenor de verbo ad verbum sequitur et est talis:

Universis presentia inspecturis, quorum interest et intererit in futurum, cupimus fore notum, quod nos Stanislaus prior provincialis provincie Polonie ac Theodoricus lector Magdeburgen(sis) ordinis fratrum predicatorum, vicarius reverendi patris magistri ordinis per provinciam Polonie, de consensu et consilio discretorum fratrum priorum, videlicet Bartholomei Cracovien(sis), Petri Wratis(laviensis), Petri Siradien(sis), Nicolai Swidnicen(sis), Iohannis Elbingen(sis), Wilhelmi Bregen(sis), limitavimus et perpetuo limitamus terminos conventuum Thoronen(sis) ex parte una et Bresten(sis) parte ex altera in Cuyavia, sic quod fratres conventus Thoronen(sis) omnes villas ad oppidum Gnyskovien(sem), ad Gnyskovien(sem) [!] directe seu indirecte pertinentes cum Wladislavia Iuveni ${ }^{b}$ civitate mendicabunt integraliter et ex toto et fratres conventus Bresten(sis) reliquas villas ut prius cum villis et parrochiis, quas fratres conventus Thoronen(sis) immediate pertinentes pronunc ad Regnum mendicare hactenus consueverunt, ipsi integraliter mendicabunt. Quicumque autem cuiuscumque status aut conditionis existat spiritu malo se instigante ausu temerario hanc divisionem terminorum pacifice et secundum Deum per nos factam quovismodo violare presumpserit, si prelatus vel presidens fuerit, ab omni officio ipso facto sit absolutus, res ad idem reassumi poterit infra tres annos ad minus, quam inhabilitationem ipsum incurrere volumus ipso facto, insuper omnibus graciis ordinis et omni voce, preterquam in sui accusatione, sit ipso facto privatus; fratres vero alii, videlicet conventuales, qui sunt et qui erunt in futurum, si presidentibus in tali facto paruerint aliter quam premissum est, ultra limites hic positos terminos mendicando tamquam spoliatores et aliene rei usurpatores carcerali pene per sententiam diffinitivam, quam in ipsos exnunc prout extunc ferimus, ipsos adiudicamus ipso facto. ${ }^{c}$ Easdem vero penam et sententiam ${ }^{-d}$ fratres conventus Snenen(sis) et quoad caput et quoad membra, et qui sunt et qui erunt in futurum, terminos predictos hic ad conventum Thoronen(sem) pertinentes invadentes ${ }^{e}$, incurrere volumus ipso facto. Actum anno Domini millesimo quadringentesimo primo in die beati Nicolai Episcopi et Confessoris, presentibus prioribus superius positis, in quorum omnium testimonium sigilla nostra presentibus sunt appensa.

Ideo vobis omnibus et singulis in virtute Spiritus Sancti et sancte obedientie ac sub pena carceris necnon sententia excommunicationis, quas quoslibet contrafacientes incurrere volumus ipso facto, districtius precipiendo impono, ne de cetero perpetuis futuris temporibus in quibuscumque terminis conventus Thoronen(sis) antedicti aliquando mendicare presumatis vel infra duos menses a notitia presentium coram me aut fratre Iohanne Arnsberg vestro provinciali duos fratres ex vobis compareatis, iura et alia, si que ad oppositum habueritis, preducturi accepturique quod iustitia exigit et requirit, ut imposterum inter conventus ipsos displicentie premissorum occasione denuo non exurgant. In casu autem, si quemadmodum dictum est non comparueritis, extunc prelibatam terminorum distinctionem dudum factam tenore presentium in novo ratifico, approbo et confirmo. In quorum omnium testimonium sigillum officii mei duxi presentibus appendendum. Datum Thoronie XXI Novembris anno Domini 
Ego frater Ludolphus sacre theologie professor, provincie Polonie ordinis predicatorum vicarius generalis et provincialis electus precognosco per subsequentia me litteras superius insertas reverendi generalis fratris Thome de Firmo et alias memoratas excopiatas fideliter vidisse, non cancellatas nec in aliqua sui parte viciatas, sed salvas et integras repperisse, quas volo in omnibus firmitatis habere, in quorum omnium fidem sigillum provincie iussi presentibus subappendi, ultima Septembris anno Domini millesimo quingentesimo decimo septimo.

${ }^{a}$ Powtórzone Or., ${ }^{b}$ Iuvene Or., ${ }^{c-d}$ Eadem vero pena et sententia $O r .,{ }^{e}$ invadent $O r .,{ }^{f}$ w Or. zostawiono wolne miejsce na ok. 20 znaków.

\section{Die Einteilung dominikanischer Terminierbezirke in Kujawien in der Mitte des 14. Jahrhunderts}

Eine Analyse der Urkunde des Provinzials Ludolf aus dem Jahre 1517

\section{Zusammenfassung}

Wichtigstes Thema des vorliegenden Beitrags stellt die Frage nach der Einteilung der dominikanischen Terminierbezirke in Kujawien während des 14. Jahrhunderts dar. Die Quellengrundlage hierfür bildet ein im Staatsarchiv Thorn aufbewahrtes Vidimus vom 30. September 1517, das von Ludolf, Provinzial der polnischen Dominikanerprovinz, ausgestellt wurde. Darin bestätigte er die Echtheit eines vom Ordensgeneral Thomas de Firmo (1401-1414) angefertigten Transsumpts. Der Verfasser wies nach, daß es sich bei dem Transsumpt um eine Fälschung handelt, die höchstwahrscheinlich vor 1469 vor dem Hintergrund der Streitigkeiten der Thorner Dominikaner mit den Franziskanern und den Karmeliten um das Bettelrecht auf dem Gebiet um Jungleslau (Inowrocław) entstand. Das gefälschte Transsumpt enthält allerdings eine echte Urkunde aus dem 14. Jahrhundert, die vom Provinzial Stanislaus zusammen mit dem Generalvikar der polnischen Provinz, dem Magdeburger Lektor Dietrich, und sechs anderen Prioren ausgestellt worden war. Die Urkunde weist ein Tagesdatum auf (6. Dezember) und wurde wohl in den Jahren 1352-1354 ausgestellt. Sie enthält ein Urteil im Streit um die Einteilung Kujawiens in Termineien, um die sich die Konvente in Thorn (Toruń) und in Brest (Brześć Kujawski) stritten. Aufgrund des Schiedsspruchs der Provinzleitung bekam der Thorner Konvent das Bettelrecht auf dem Gebiet des Dekanats Jungleslau zugesprochen, das das Gegend von Jungleslau und Gniewkowo umfaßte; die Brester Dominikaner sollten hingegen die Seelsorge auf dem Gebiet von Brest betreiben. Im Rahmen der Untersuchung ließen sich einige Informationen zur Reihenfolge der mittelalterlichen Dominikanerprovinziale verifizieren und berichtigen. So übernahm der im Urteil erwähnte Provinzial Stanislaus dieses Amt höchstwahrscheinlich in den Jahren 1352-1354 und verwaltete es bis 1355. Beim heutigen Kenntnisstand läßt sich nicht mit Sicherheit sagen, wer dieses Amt in den Jahren 1344-1352 innehatte. Der Name Johannes Struś in der offiziellen Liste der polnischen Provinziale erwies sich als eine falsche Lesart des Namens Johannes Arnsberg. Es konnte nachgewiesen werden, daß Johannes Arnsberg der unmittelbare Nachfolger von Andreas Rusiniec (1396-1401/1402) war und wohl bereits 1402 an die Spitze der Provinz gelangte. 


\title{
Divisions of Dominican monastic districts in Kuiavia in mid-14th century
}

A study of provincial superior Ludolf's document of 1517

\begin{abstract}
The main subject of the paper is the question of the division of Dominican collecting disctricts in Kuiavia in the $14^{\text {th }}$ century. The source basis is the vidimus dated 30 September 1517, issued by Ludolf, the provincial superior of the Polish Dominican province. Ludolf confirmed the authenticity of the transumpt prepared by Thomas de Firmo, the general of the order (1401-1414). The author proves that the transumpt is a forgery, most probably produced before 1469 . Nevertheless, the fake transumpt contains an authentic $14^{\text {th }}$ century document issued by provincial superior Stanisław together with vicar general for the Polish province, the Magdeburg lector Theodoric and six priors. The document probably dates from 1352-1354 and is the decree concerning the boundaries of collecting districts in Kuiavia. The sides were the Dominican convents in Torun and Brześć Kujawski. By the decision of the province, the Torun convent received the right of collecting in the deanery of Inowrocław, covering the territories of the Duchy of Gniewkowo and starostwo of Inowrocław, while the Dominicans of Brześć were allowed to conduct their activities on the area of that part of Kuiavia.
\end{abstract}

Translated by Rafal T. Prinke 